\title{
Academic Rigor and Dedication to Competitive Sport in Young People 12-18 Years: Major Social Issues
}

\author{
Josep Solà Santesmases
}

Ramon Llull University, Barcelona, Spain

\section{ABSTRACT}

Quantitative study with the aim of linking the academic performance of students who are high-level athletes in Catalonia (Spain) and who do not have any institutional support (high-performance centre, reduction of subjects, etc.) or belong to any educational institution with adapted curriculum (90-95\% of households), compared to sedentary students who play sports only occasionally.

The study divided students into two groups by age: $12,14,16$ and 18 years old (secondary school). The general group (GG) was made up of students who did sports at school, did not participate in major competitions, and the weekly training requirement did not exceed 3 hours $(\mathrm{N}=262)$. The group of athletes (AG) is made up of students who at least competed for the Championship of Catalonia (swimming and basketball) and the weekly training requirement exceeded 4.30 in younger students $(\mathrm{N}=212)$. The questionnaires were constructed in order to gather academic information, highlighting the grades of the subjects for the second evaluation of the 2008-09 academic year and full-time sports data for training (day session, hours, competition) and schooling (public or private).

We found a significant correlation (0.99) in comparing the evolution of differences between the grades of the groups. Supporting an extraordinary demand for training, and increasing with age, student athletes have better academic performance throughout secondary education. However, this trend is broken in high school, coinciding with the highest dedication to training.

Two other important considerations are highlighted in the study: first, the GG presented inactivity levels which increase linearly with age and this is more prominent in females, and secondly, the enrolment of the school is basically $\mathrm{AD}$ private state-assisted and not public system, which can make us think about whether the family ideology also influences the sports options for children.

KEYWORDS academic rigor, competitive sport, type of schooling

\section{Theoretical introduction}

When consulting the bibliography, multiple references to studies that relate the academic results with the dedication to the sport are found. A good initial reference is the Taras (2005) article, which after collecting 14 studies, attempts to correlate physical activity with academic achievement in a 
specific segment of the population. Some of these studies focused on the impact of gymnastics programs, others on sport dedication and others on involvement in out-of-school activities. But the studies present such a variation of results that it becomes difficult to affirm if correlations between the level of physical activity and improvements in academic performance were casual or if they were really due to cause and effect.

In the context of Catalonia, a study based on a survey of 6,928 students between 14 and 19 years old in Catalonia high schools demonstrated that the teenagers who made voluntary physical activity at least once a week, not only achieved better grades, but they also felt better about their body and had better social relationships with their family and in the school environment (Surís and Parera 2005). The study argued that if physical activity was made, the risk of achieving bad grades was reduced by $26 \%$ in boys and $34 \%$ in girls.

Heinemann (1998) explains that the more time one devotes to training and to competitions, the fewer possibilities there are to prepare oneself for the future. High-level sport is often a synonym for of impossibility maintaining academic performance, since there is a chronological coincidence with both activities in the personal development of the sportsman during adolescence and youth. In a concise way, Wylleman and Lavallee (2003) explain this evolution of the sportsman with age, who has to combine physiological development found at every age with the educational demands of every stage and the changing social relationships in the cultural context where one lives (transitions). Therefore, without the same conditions of cultural education, future professional prospects could be uncertain when the sports life ends, or at least the sportsman could be at a disadvantage with regard to the general population.

Finally, the possibility of the high-level sportsman focusing on his/her life in a different way is proposed to the general population: not having to be like the rest of the people, why precisely not all citizens do two activities as demanding as student sportsmen do. From here the increasingly more developed and studied idea appears in the Personal Project (Rock 2006b). The personal project, as the author writes, is not a new concept but it has been revived in western society and has relevance to sportsmen and their special problems. The personal project is an exercise of autonomy based on the knowledge of each subject; the personal project appears from the reflection and from the wisdom of each one, "like something differentiated but compatible with the collective projects" (Roca 2006b, p. 131).

\section{Approach to the research}

The proposed hypothesis that will have to be accepted or rejected is the following: there are no differences in academic performance between the general population group (GG) and the group of sport population (GS) at the youngest ages, but beginning at a certain educational stage, the impossibility of combining studies and training is found to be detrimental to the academic performance of the population of sports pupils.

If there is really a moment when the academic balance between both population groups is broken, it will be interesting to discover at which evolutionary moment the pressure of studies becomes incompatible with the number of hours of dedication to training required for high performance, and it is necessary to make the decision to leave. To analyze this datum would be relevant in order to focus on efficient educational and political actions that intervened directly in this more problematic educational stage to combine studies and sport.

\section{Goals}

Main goal: checking the existence of statistical correlation among the academic performance and the hours of dedication to the sports training of two different groups called general population and sporting population of a non-integrated educational model in an evolutionary and diachronic approach. 
Secondary goals: checking the existing correlations in relation to gender, age, education, number of hours of dedication to the study and number of hours devoted to out-of-school activities and which specific type of out-of-school activities are carried out. Also, to check if the current sports performance (ranking, participation in Catalan or Spanish national teams or minutes of game), can be a clear condition to sustain the effort of combining sports and academic performance.

\section{Method}

The focus of this study will be quantitative, because the object of the research is to gather and to analyze datum in order to test the proposed hypothesis through the numerical datum and the statistical support in order to establish patterns of behaviour in the population (Hernández, Fernández and Baptista 2003). The design of the research has a descriptive reach and, especially, to observe possible correlations. The descriptive study intends to specify the properties, characteristics and relevant features of the population that it examines. The study that is presented is transversal descriptive research, since at the same moment in time (May of 2009), datum that belonged to four population groups differentiated by ages was gathered: 12 years (born in 1997, primary), 14 years (born in 1995, secondary), 16 years (born in 1993, secondary) and 18 years (born in 1991, high school).

\subsection{Sample of the population.}

The total sample has been from 474 students. To check if the dedication to the sports training can affect the academic grades, two population groups are established and are clearly differentiated in order to be able to make the comparison:

a) general group ( $G G, n=262)$ : in this population the students are between 12 and 18 years old and fulfill the following requirements:

- pupils who do not carry out any type of sports activity,

- if they do sport, the weekly dedication is clearly less than 3 hours of training.

- without competitive aspiration (leisure sports) or without options in the Championship of Catalonia.

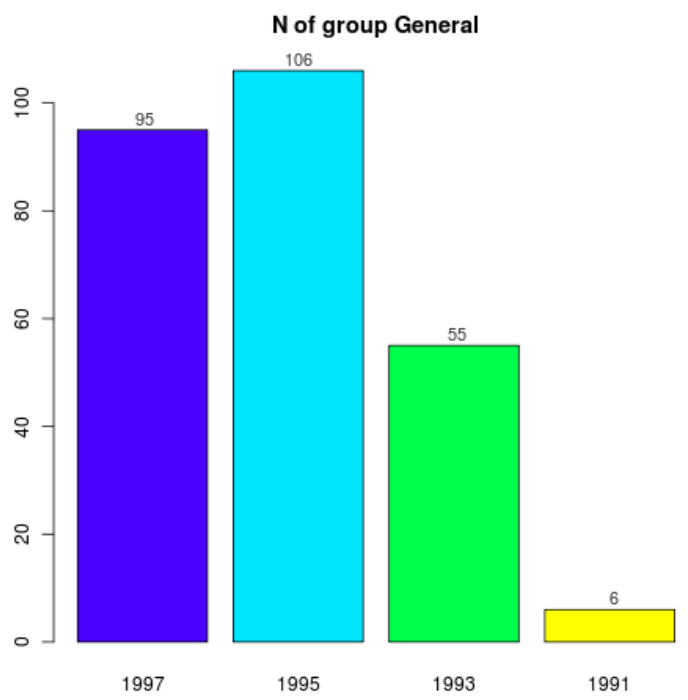

Figure 1. Sample of general group (N) 
Table 1. Sample of general group

\begin{tabular}{lccc}
\hline Age & \multicolumn{3}{c}{ GG participants } \\
\hline 12 years old & 44 & Girls & Total \\
14 years old & 44 & 62 & 95 \\
16 years old & 30 & 25 & 106 \\
18 years old & 3 & 3 & 55 \\
\hline Total & 121 & 141 & 6 \\
\hline
\end{tabular}

b) group of sport (GS, $n=212$ ): in this population the students are between 12 and 18 years old and fulfill the following requirements:

- pupils who practice sport with a weekly dedication to training of over $4 \mathrm{~h} 30 \mathrm{~m}$ from the youngest ages (12 years),

- with minimum competitive aspiration of participating in the Championship of Catalonia of the corresponding modality (basketball and swimming),

- without any type of institutional help or project for sportsmen that help them to combine the demand of training and school academic life.

Table 2. Sample of group of sport (gender and sport modality)

\begin{tabular}{lccccccc}
\hline & \multicolumn{9}{c}{ GS participants } & \multicolumn{3}{c}{ Girls } \\
\hline Age & Boys & \multicolumn{5}{c}{ Total } \\
12 years old & Basketball & Swimming & Total boys & Basketball & Swimming & Total girls & Twim \\
14 years old & 28 & 19 & 47 & 11 & 27 & 38 & 85 \\
16 years old & 28 & 9 & 37 & 15 & 11 & 26 & 63 \\
18 years old & 13 & 6 & 19 & 7 & 9 & 16 & 35 \\
\hline Total & 14 & 4 & 18 & 8 & 3 & 11 & 29 \\
\hline
\end{tabular}

The sample of sportsmen clearly loses subjects with age. The slope is particularly reflected in a clear way in swimming; however, in basketball, the numbers sustain why it is necessary to have a minimum of 10 players to make a team and to be able to compete, regardless of the category.

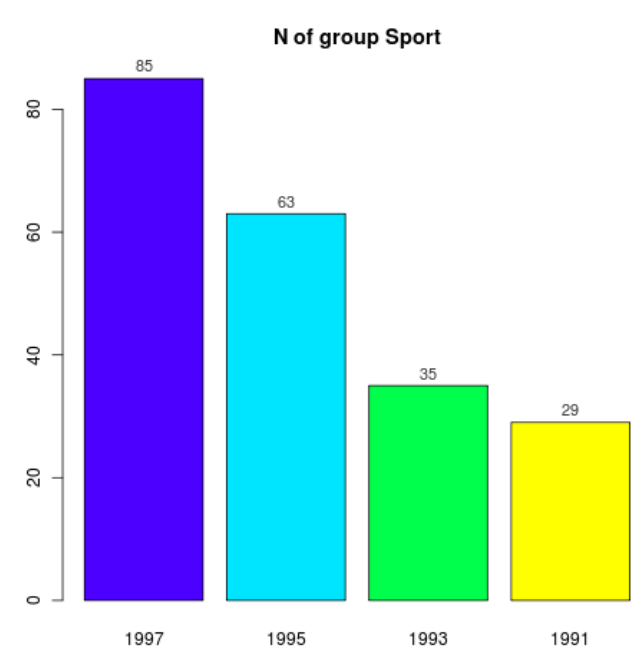

Figure 2. Sample of group of sport (N)

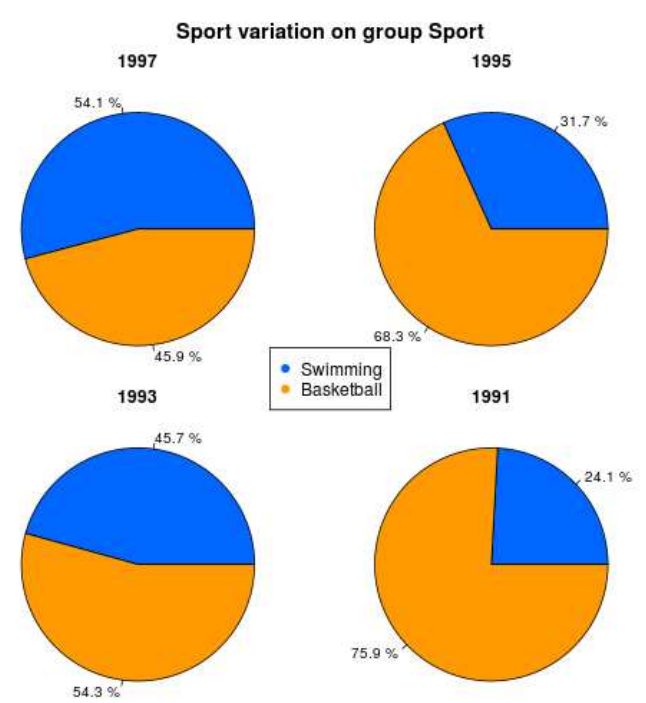

Figure 3. Sample of group of sport (sport modality)

The total number of participants adding up the general group and the sporting group is 474 subjects (Table 3). 
Table 3. Total Sample $(\mathrm{GG}+\mathrm{GS})$

\begin{tabular}{lccc}
\hline Age & General & $\begin{array}{c}\text { Total participants } \\
\text { Athletes }\end{array}$ & Total \\
\hline 12 years old & 95 & 85 & 180 \\
14 years old & 106 & 63 & 169 \\
16 years old & 55 & 35 & 90 \\
18 years old & 6 & 29 & 35 \\
\hline Total & 262 & 212 & 474 \\
\hline
\end{tabular}

\subsection{Instruments of quantitative datum collection}

To gather the quantitative datum of both the general population as well as of the sporting population, a questionnaire, totally closed and as objective as possible, was constructed to gather the following basic datum for each subject participating in the study:

- GENERAL DATUM: date, place of realization, town, hour.

- PARTICULARS: person who answers the questionnaire (father, mother, tutor, student, etc.), age, dates of birth and gender.

- ACADEMIC DATUM: course and educational stage, weekly hours, name of the educational centre, type of centre (public, state-assisted or private). And especially, grades of all the subjects of the second evaluation of the academic year 2008-09 (academic report of Easter grades). They were also asked for hours of dedication to studies (during the week and at weekends) and other out-of-school activities (how many, which, hours of dedication).

- SPORT DATUM: category, name of the sports centre they belong to and type (club, school, independent). And especially, dedication to the sport of reference: days, sessions, hours, number of competitions, was completed with their current up-to-date position in the ranking or if he/she had participated in national teams (Catalan or Spanish).

The questionnaire was completed for the academic datum as well as for the sports datum with a small margin for the opinion, very brief, in the form of a brief question. Each questionnaire was introduced individually using the Microsoft Excel program, and constructing some datum tables that followed the structural axes of the models of questionnaires: grouped by ages of similar models (19971995 and 1993-1991), and with respect to the differences between both population samples, general and sportsmen. With the Excel tables, the $R$ of Core Team program and the quantitative information retrieved, they made the first descriptive statistical, graphical calculations and correlations. The enforceable ethical minimums in the educational research and the anonymity of the datum obtained from each subject was guaranteed and protected to prevent publication without authorized consent.

\section{Results}

A strong linear and direct dependence among the differences of the medium variable of grades, with a coefficient of correlation of Pearson of 0,997 , has been found. The significance of this finding means that as the age and educational level increase, the differences between the grades of the sportsmen and of the general population decrease. The following graph shows the line of regression calculated theoretically, adjusted to the lines about the cloud of real dispersion points. It can be observed that the difference is minimum and that the obtained datum fits to the straight line of Pearson with a maximum degree of signification. 
Difference on qualifications by groups and ages

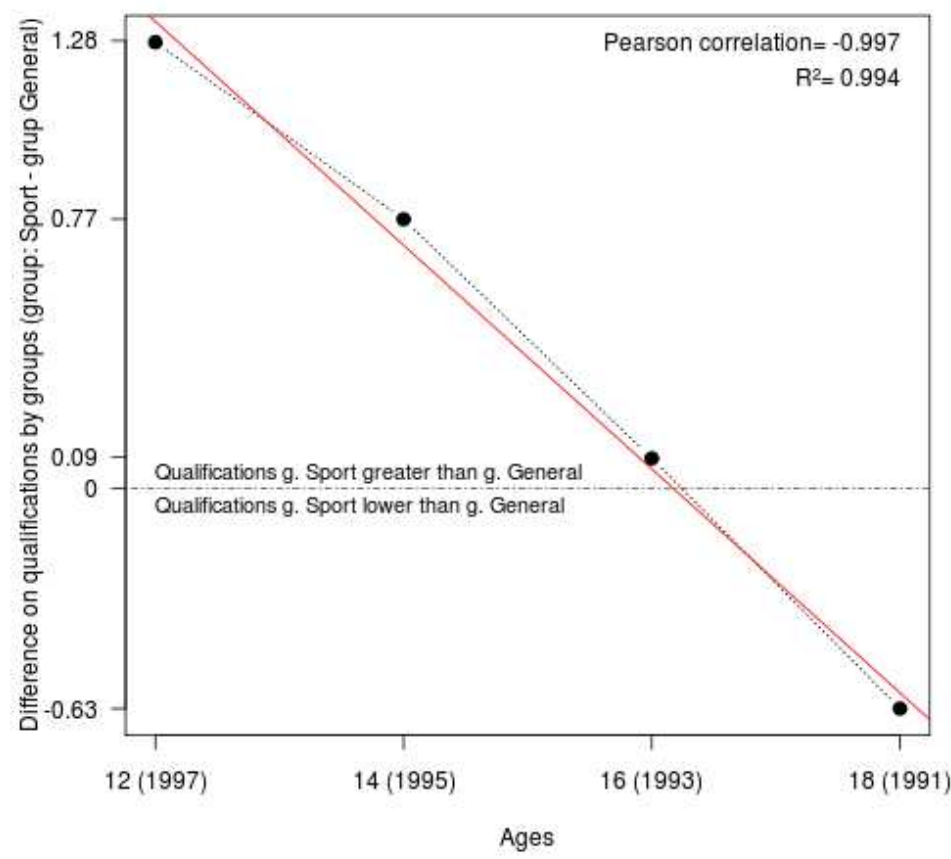

Figure 4. Differences of grades for groups and for ages

In particular, we want to consider the secondary goals of research with strong implications for social character.

\subsection{General Group (GG) who do not participate in sport}

In the sample of the general population, there are the subjects who do leisure sport - noncompetitive and with a few hours of dedication - but totally advisable for a healthy lifestyle. Unfortunately, as in the sample datum, there are a very high percentage of youngsters in our country who do not do any type of physical activity or leisure sport, even out-of-school; an important percentage of the population that benefits from regular physical practice. This fact reveals two ideas:

1. A very young sample of people, both boys and girls between the ages of 12 and 18 years old, shows a very clear trend of growth in accordance with the evolution of the age.

2. The detection of a sedentary lifestyle is higher in the feminine gender. There are clear differences of gender in relation to the percentage of population that does not do sport.

Table 4. Physical inactivity among studied girls and boys

\begin{tabular}{ccc}
\hline No sport & Girls & Boys \\
\hline Minimum range & $31.37 \%(12$ years old $)$ & $11 \%(14$ years old $)$ \\
Maximum range & $66.6 \%(18$ years old $)$ & $33 \%(18$ years old $)$ \\
\hline
\end{tabular}

The increasing evolutionary trend of this behaviour remains reflected when at 18 years the inactivity shows the highest percentages. At any rate, the difference between genders is exaggerated in all the analyzed age sets. The maximum rank of inactivity in boys (18 years old) is practically the same as the rank of minimum inactivity in the girls (12 years old), highlighting that this high degree of a lack of sports practice in women already is already present in very young ages (12 years). 


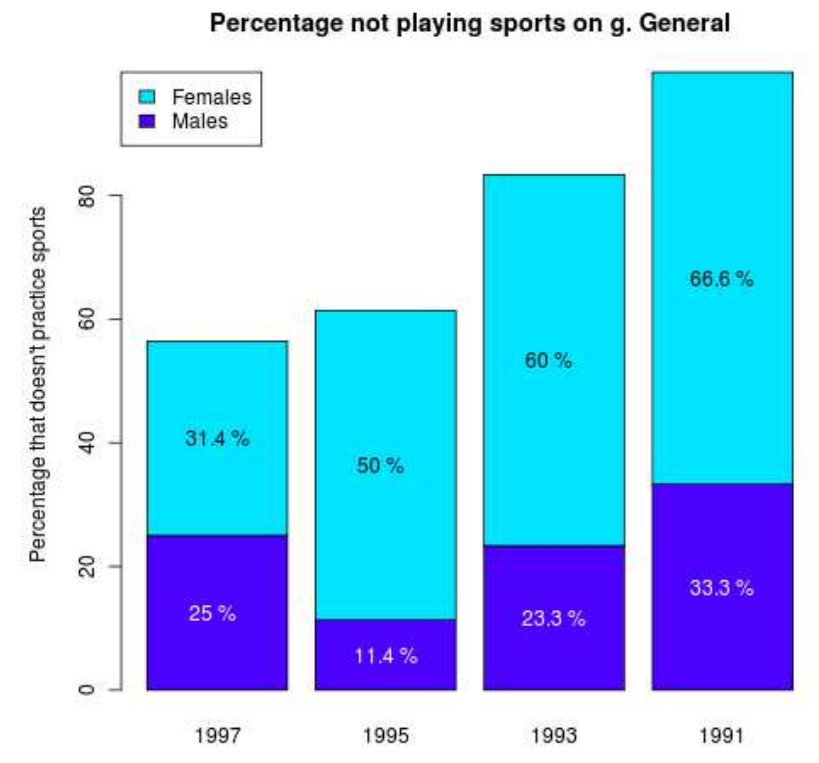

Figure 5. Percentage of general group (GG) who doesn't practice sport

\subsection{Type of schooling in Group of Sport (GS)}

The distribution of the sample of sportsmen in relation to the modality of education (public or private) presents itself as particularly falling in all age groups in favour of the state-assisted private education, and is much more relevant. If the educational systems favour a type of ideology or values, in this case it seems quite distinguished that reality shows that the values of the sport of competition are more linked to state-assisted private education than to public education. From the world of pedagogy, the neo-liberal ideology of the western world, an ideology drenched in competition, demand and efficiency (Santos Guerra 2009), is understood: that the one what solidifies these values is perhaps the private educational model to a greater degree?

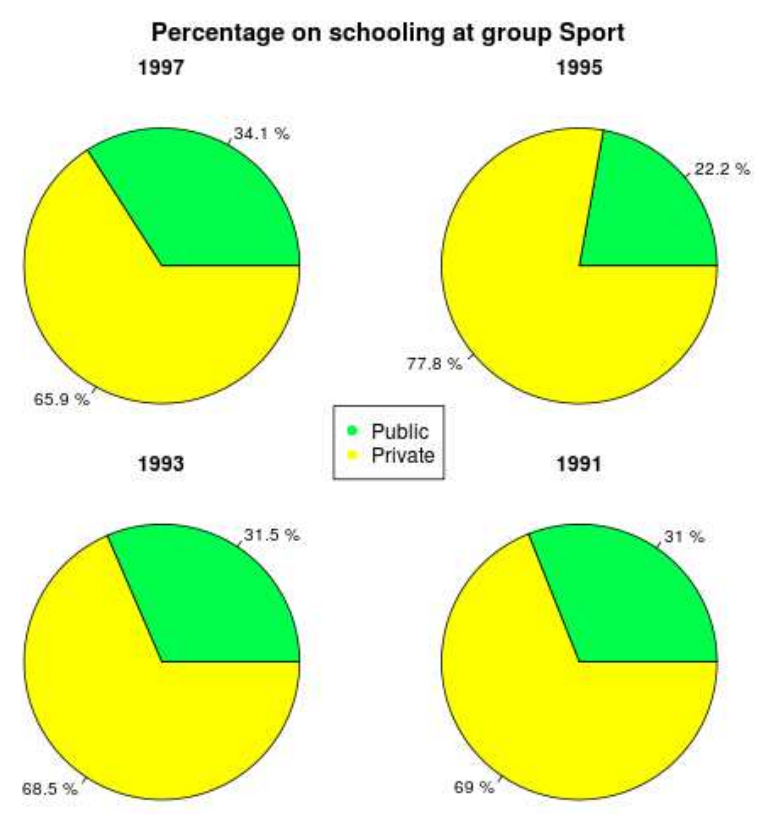

Figure 6. Type of schooling in the group of sport (GS) 


\subsection{Validate Physical Education}

On the other hand, before validating physical education in sporting students, it would be necessary to make several considerations. It appears, in the first place, as extracted from the quantitative study, in a table with the evolution of the physical education grade:

- the subject that has achieved the best grades are the sporting student of all ages, more meritorious if it has been observed that it is quite the average of grades to the youngsters high,

- the average grades for those participating in physical education in all ages are always superior to those of the general population, taking into consideration that for 1995, it is also a maximum grade for this general population,

- curiously, the difference of grades of the physical education subject follows exactly the same behaviour as the global one, on average, of evaluated grades.

Table 5. Evolution of the physical education grade

\begin{tabular}{lccc}
\hline Grades & General Group & Group Sport & Difference (\%) \\
\hline 1997 (12 years) & 6,87 & 8,47 & $+1,6(16 \%)$ \\
1995 (14 years) & 7,25 & 8,63 & $+1,38(13,8 \%)$ \\
1993 (16 years) & 8,02 & 8,46 & $+0,44(4,4 \%)$ \\
\hline
\end{tabular}

Depending on this datum, logician does not seem to the sportsmen of competition of the subject who achieve better grades and that the final average can climb up for them to curricular level more to exempt. Mechanisms should be found to make physical education compatible with a pupil's dedication to sports practice, if it is not counter-productive to the training, specific to the sport that he/she is carrying out, and that it allows him/her to maintain a high level of academic grades.

On the other hand, there are the personal considerations as a physical educator. If it is defended that the academic demand of the sports students should not be lowered, this also has to include the physical education and its integral educational aspects. On the fringe of the coolness of the former quantitative datum, it makes us think that the goals that the curriculum establishes for physical education are not fully designed for the pupil who devotes some 10 hours to the sport, in a voluntary way, on average compared to the one who only devotes 2 hours, and that establishes the subject in a compulsory and difficult way. The people who have shared the competitive sport can give authentic lessons about the fact that he tries hard every day, has discipline, looking after himself/herself, knowing how to win and how to lose when the opponent is superior, that journeys can be shared, working together with those who the next day could be opponents the list of experiences is long. Obviously that some concretion of the curricular goals of physical education can remain a child driven away from the specificity of a specific sport modality, but not so far away how the sedentary population is it of the rest of goals.

\section{Conclusions}

Main goal: the goal grades are fulfilled in a significant way from the variable on obtaining a correlation of the differences for groups from the 0.99 . Significant correlation cannot be demonstrated in the times of training, only to suppose that one decidedly found the other one.

The general population has maximum grades in the higher academic years; the sports population has the maximum grades in the academic years of younger people. The trend is also contemplated in the minimum grades, which correspond to academic years of young people in the general population and, however, correspond to courses of older people in the sporting population.

A possible explanation to the fall of the academic performance of the sportsmen can be seen in the study of the behaviour of the variable hours of training. The difference of dedication to the training between the general group and the sporting group is huge when at weekly times, hours that they do not 
calculate the physical fatigue or the possible hours of travel to and from the sports centres. However, the sporting students demonstrate that they can have academic performances over the inactive people during the entire compulsory secondary education.

Secondary goals: The trend of the inactivity in the GG is increasing. and at 18 years shows the highest percentages. The difference between genders in all the analyzed age sets is exaggerated: the maximum level of inactivity in the boys (18 years old), is practically the same as the minimum level in the girls (12 years old), and this high degree of lack of sports practice in women is already seen in very young ages (12 years).

The popular belief that, if at young ages they do not have out-of-school or sports activities to dedicate oneself to studying, does not seem will increase the volume a certain of hours that the pupils will devote to the study. The research shows that the general population, without demanding sports commitments, studies fewer hours between 12 and 14 years old than the sports population. For such reasons, it seems that it is not correct to remove children from the sports activities supposing that in this way they will devote more hours to study.

\section{REFERENCES}

Anguera, T. (2009). Avaluació en la intervenció psicopedagògica. Aloma. Revista de Psicologia, Ciències de l'Educació i de l'Esport, 23-24, 101-108.

Cano, M. (2008). Com educar avui pel demà? Proposta per un model integral de centre d'innovació educativa. Generalitat de Catalunya: Departament d'Educació (Projecte de Recerca amb llicència d'estudi). Retrieved December 18, 2008 from http://www.xtec.cat/ mcano/avui_x_dema/index1.html.

Cecić Erpič, S.; Wylleman, P. \& Zupancic, M. (2004). The effect of athletic and non-athletic factors on the sports career termination process. Psychology of Sport and Exercise, 5, 45-59.

Cultura, Departament de (2002). Decret 337/2002, de 3 de desembre, sobre l'alt rendiment esportiu.

Educació, Departament de (2007). Decret 143/2007, de 26 de juny, pel qual s'estableix l'ordenació dels ensenyaments de l'educació secundaria obligatòria.

Educació, Departament de (2009). Resolució de 29 de maig de 2009 relativa a l'organització i el funcionament dels centres públics d'educació secundària per al curs 2009-2010.

Ferrer, F., Valiente, O., Castel, J. L. (2008). Equitat, excel-lència i eficiència educativa a Catalunya. Una anàlisi comparada. Una ullada a l'Informe PISA 2006. Barcelona: Fundació Jaume Bofill.

Fullat, O. (2003). Mètode i ciències humanes. Aloma. Revista de Psicologia, Ciències de l'Educació i de l'Esport, 12, 15-36.

González, Ma . D., Bedoya, J. (2008). Después del deporte, ¿qué? Análisis psicológico de la retirada deportiva. Revista de Psicología del Deporte, 17(1), 61-69.

Grobett, F. J. (1985). Psycho-social adjustment of athletes to retirement. In A. K. Bunker, R. J. Rotella \& A. Reilly (Eds.), Sport psychology: Psychosocial considerations inmaximizing sport performance (pp. 288-294). Ithaca: Movement Publications.

Heinemann, K. (1998). Einführung in die Soziologie des Sports. Schorndorf: Hofmann. $4^{\mathrm{a}}$ ed.

Hernández, R., Fernández, C., Baptista, P. (2003) Metodología de la Investigación (3ª ed.). México, McGrawHill Interamericana.

Murphy, G. M., Petitpas, A. J. \& Brewer, B. W. (1996). Identity foreclosure, athletic identity and career maturity in intercollegiate athletes. The Sport Psychologist, 10, 239-246.

R Development Core Team. R: A Language and Environment for Statistical Computing. R Foundation for Statistical Computing, Vienna, Austria.

Roca, J. (2006a). Psicologia: una introducció teòrica. Sèrie Liceu Psicològic. Girona: Documenta Universitaria.

Roca, J. (2006b). Automotivación ( $1^{\mathrm{a}}$ ed.). Barcelona, Paidotribo.

Sánchez, R. (2003). Tendències etnogràfiques postmodernes en la investigación social de l'esport: de l'antropologia comprensiva al desenvolupament comunitari. Aloma. Revista de Psicologia, Ciències de l'Educació i de l'Esport, 12, 58-69.

Santos Guerra, M. A. (2009). La Evaluación Formativa y Compartida en Educación Superior. Experiencias, técnicas y recursos (Ponencia Marco). IV Congreso Internacional de Evaluación Formativa en Docencia Universitaria, 17-19 Septiembre (Segovia). 
Suris, J. C., Parera, N. (2002). Enquesta de salut als adolescents escolaritzats de Catalunya 2001. Barcelona: Fundació Santiago Dexeus.

Surís, J. C., Parera, N. (2005). Don't stop, don't stop: physical activity and adolescence. International Journal of Adolescent Medicine and Health, 17(1), 67-78.

Taras, H. (2005). Physical Activity and Student Performance at School. Journal of School Health, 75(6), 214218.

Vilanova, A (2009). El procés d'inserció laboral d'esportistes olímpics a Catalunya. Tesi Doctoral no publicada. Departament de Teoria i Història de l'Educació, Institut Nacional d'Educació Física de Catalunya: Universitat de Barcelona.

Werthner, P. \& Orlick, T. (1986). Retirement experiences of sucessful olympic athletes. International Journal of Sport Psycology, 17, 337-363

Williams-Ryce, B. T. (1996). After the final snap: cognitive appraisal, coping, and life satisfaction among former collegiate athletes. Academic Athletic Journal Spring, 30-39.

Wylleman, P., De Knop, P., Menkehorst, H., Theeboom, M. \& Annerel, J. (1993). Career termination and social integration among elite athletes. Comunicació presentada al $8^{\text {th }}$ world congress of sport psychology, 902-905, Lisbon.

Wylleman, P., Lavallee, D. (2003). A developmental perspective on transitions faced by athletes. In A. M. Weiss (Ed.), Developmental sport psychology (pp. 507-527). Morgantown: WV: Fitness Information Technology.

AUTHOR'S ADDRESS: $\quad$ Josep Solà Santesmases

C. Del Cister, 34

08022 Barcelona, Spain

Email: JosepSS@blanquerna.url.edu 